\title{
Characterization of the Biogenic Manganese Oxides Produced by Pseudomonas putida strain MnB1
}

\author{
Shaofeng Jiang, Do-Gun Kim, Jeonghyun Kim, Seok-Oh Ko ${ }^{\dagger}$ \\ Department of Civil Engineering, Kyung Hee University, Yongin, 449-701, Republic of Korea
}

\begin{abstract}
Biogenic Mn oxides are expected to have great potential in the control of water pollution due to their high catalytic activity, although information on biological Mn oxidation is not currently sufficient. In this study, the growth of a Mn oxidizing microorganism, Pseudomonas putida MnB1, was examined, with the Mn oxides formed by this strain characterized. The growth of $P$. putida MnB1 was not significantly influenced by $\mathrm{Mn}$ (II), but showed a slightly decreased growth rate in the presence of $\mathrm{Pb}$ (II) and EE2, indicating their insignificant adsorption onto the cell surface. Mn oxides were formed by $P$. putida MnB1, but the liquid growth medium and resulting biogenic solids were poorly crystalline, nano-sized particles. Biogenic Mn oxidation by P. putida MnB1 followed Michaelis-Menten kinetics, with stoichiometric amounts of Mn oxides formed, which corresponded with the initial Mn(II) concentration. However, the formation of Mn oxides was inhibited at high initial Mn(II) concentration, suggesting mass transfer obstruction of Mn(II) due to the accumulation of Mn oxides on the extracellular layer. Mn oxidation by $P$. putida $\mathrm{MnB} 1$ was very sensitive to $\mathrm{pH}$ and temperature, showing sharp decreases in the Mn oxidation rates outside of the optimum ranges, i.e. $\mathrm{pH}$ 7.43-8.22 and around $20-26^{\circ} \mathrm{C}$.
\end{abstract}

Keywords: Biogenic Mn oxides, Pseudomonas putida MnB1, Mn oxidation kinetics

\section{Introduction}

Manganese oxides (Mn oxides) promote the oxidation of a variety of synthetic and natural organic pollutants, such as humic substances, phenols, endocrine disrupters and chlorinated organic compounds, due to their high redox potential [1-4]. Recently, biologically generated Mn oxides have been of increasing interest due to their high available surface area [5]. Microorganisms (bacteria and fungi) that oxidize $\mathrm{Mn}(\mathrm{II})$ to $\mathrm{Mn}$ (IV) oxides are known as Mn-oxidizing microorganisms. The Mn-oxidizing bacteria present in raw water can grow and reproduce under appropriate conditions and are able to oxidize Mn(II), with precipitation of the oxidized form, Mn(IV). The biogenic Mn oxides formed by Mn-oxidizing bacteria have many specific characteristics, such as high specific surface areas and reactivities, and can be used for adsorbents, catalysts, and oxidants or reductants [6]. Under circumneutral conditions, the microbial oxidation of $\mathrm{Mn}$ (II) proceeds several orders of magnitude faster than the abiotic oxidation, such as in homogenous and mineral surfacecatalytic reactions [5]. Therefore, the microbial Mn(II) oxidation process has gained increasing attention with regard to its environmental applications.

Studies on biogenic Mn oxidation have focused on several organisms, including Bacillus sp. strain SG-1, which is a grampositive, rod-shaped bacterium that produces Mn oxidizing spores [7], Leptothrix discophora strains SS-1 and SP-6, which are sheet-forming bacteria, living in fresh water [8-9], and Pseudomonas putida strains MnB1 and GB-1, which are gram-negative bacteria that produce Mn oxides on the cell surface, and live in both fresh water and soil [10-11].

The objectives of this study were to characterize the growth of $P$. putida $\mathrm{MnB1}$, investigate the kinetics of $\mathrm{Mn}$ (II) oxidation by $P$. putida $\mathrm{MnB1}$ and examine the property of the biogenic $\mathrm{Mn}$ oxides produced. Factors affecting the growth of $P$. putida $\mathrm{MnB} 1$ and $\mathrm{Mn}(\mathrm{II})$ oxidation were also investigated.

\section{Materials and methods}

\subsection{Culture and medium}

Pseudomonas putida strain MnB1 was supplied by the American Type Culture Collection (ATCC), under number 23483. The oxidation of Mn was demonstrated using \#279 Broth, as recommended by the ATCC, the composition of which is shown in Table 1 . The culture was transferred to this medium and incubated at $26^{\circ} \mathrm{C}$. The formation of black precipitates indicated the presence of Mn oxides. The precipitates usually appeared in approximately $24 \mathrm{hr}$. The bacteria were cultured in \#3 Broth (Difco 0003) and \#3 Agar (Difco 0001), as recommended the ATCC, the com-

Received September 10, 2010 Accepted October 28, 2010

cc This is an Open Access article distributed under the terms of the Creative Commons Attribution Non-Commercial License (http://creativecommons. org/licenses/by-nc/3.0/) which permits unrestricted non-commercial use, distribution, and reproduction in any medium, provided the original work is properly cited.
${ }^{\dagger}$ Corresponding Author

E-mail: soko@khu.ac.kr

Tel: +82-31-201-2999 Fax: +82-31-202-8854 
positions of which are presented in Table 2. The liquid growth medium for Pseudomonas putida MnB1 was prepared, as presented in Table 3. Trace element solution in Table 3 includes 6.4 $\mathrm{mg} / \mathrm{L} \mathrm{CuSO}_{4}, 44 \mathrm{mg} / \mathrm{L} \mathrm{ZnSO}_{4} 7 \mathrm{H}_{2} \mathrm{O}, 20 \mathrm{mg} / \mathrm{L} \mathrm{CoCl}_{2} \cdot 6 \mathrm{H}_{2} \mathrm{O}$ and 13 $\mathrm{mg} / \mathrm{L} \mathrm{Na}_{2} \mathrm{MoO}_{4} 2 \mathrm{H}_{2} \mathrm{O}$.

\subsection{Growth of Pseudomonas putida strain MnB1}

Batch experiments were conducted in $300 \mathrm{~mL}$ Erlenmeyer culture flasks (Duran) with the liquid growth medium. For each batch experiment, one tube of $P$. putida $\mathrm{MnB} 1$ was firstly taken out of the ultralow temperature refrigerator and transferred to several Petri dishes containing \#3 Agar (Difco ${ }^{\mathrm{TM}}$ ) using a loop. The Petri dishes were then incubated at $30^{\circ} \mathrm{C}$ for $24 \mathrm{hr}$. All bacteria were transferred from the Petri dishes to a glass vial containing liquid growth medium using a loop, with $2 \mathrm{mg}$ of bacteria per $1 \mathrm{~mL}$ of medium. After mixing, $1 \mathrm{~mL}$ of the bacteria suspension was added to a flask containing $100 \mathrm{~mL}$ of the liquid growth broth. The bacteria were incubated at $26^{\circ} \mathrm{C}$ and $150 \mathrm{rpm}$ in a reciprocating shaker. To determine the effects of the initial amount of bacteria and $\mathrm{Mn}$ (II) concentration, the growth of $P$. putida MnB1 was investigated with 0.1-0.9 mL of the bacterial suspension and 0-100 mg of $\mathrm{Mn} / \mathrm{L}\left(\mathrm{MnCl}_{2}\right)$. The effects of heavy metals and $17 \alpha$-ethinylestradiol (EE2) were also studied. The growth curves of $P$. putida MnB1 in the presence of $10-100 \mu \mathrm{M} \mathrm{Pb}(\mathrm{II})$ $\left(\mathrm{Pb}\left(\mathrm{NO}_{3}\right)_{2}\right)$, as a representative heavy metal, and those with 1-3 $\mathrm{mg} / \mathrm{L}$ EE2 were investigated. All batch experiments were carried out for $72 \mathrm{hr}$, with three replicates. The growth curves over a 48 hr period were obtained because the stationary phase was attained after $24 \mathrm{hr}$ for all experiments. The optical density at 600 $\mathrm{nm}$ (OD600), measured using a spectrophotometer (UV-mini

Table 1. Composition of \#279 Broth (ATCC ${ }^{\mathrm{TM}}$ )

\begin{tabular}{lc}
\hline Component & Concentration in deionized $\mathrm{H}_{2} \mathrm{O}(\mathrm{g} / \mathrm{L})$ \\
\hline $\mathrm{MnCO}_{3}$ & 1.0 \\
$\mathrm{Fe}\left(\mathrm{NH}_{4}\right)_{2}\left(\mathrm{SO}_{4}\right)_{2} \cdot 6 \mathrm{H}_{2} \mathrm{O}$ & 0.15 \\
Yeast extract & 0.075 \\
Sodium citrate & 0.15 \\
$\mathrm{Na}_{4} \mathrm{P}_{2} \mathrm{O}_{7} \cdot 10 \mathrm{H}_{2} \mathrm{O}$ & 0.05 \\
$\mathrm{Agar}$ & 10.0 \\
\hline
\end{tabular}

Table 2. Compositions of Nutrient Broth and Nutrient Agar (Difco ${ }^{\mathrm{TM}}$ ).

\begin{tabular}{ll}
\hline Nutrient \#3 Broth (per liter $\mathrm{H}_{2} \mathrm{O}$ ) & Nutrient \#3 Agar (per liter $\mathrm{H}_{2} \mathrm{O}$ ) \\
\hline Beef Extract : $3.0 \mathrm{~g}$ & Beef Extract: $3.0 \mathrm{~g}$ \\
Peptone : $5.0 \mathrm{~g}$ & Peptone : $5.0 \mathrm{~g}$ \\
& Agar : $15.0 \mathrm{~g}$ \\
\hline
\end{tabular}

Table 3. Composition of the liquid growth medium [12].

\begin{tabular}{lc}
\hline Component & Concentration in deionized $\mathrm{H}_{2} \mathrm{O}(\mathrm{g} / \mathrm{L})$ \\
\hline Yeast extract & 0.5 \\
Casamino acids & 0.5 \\
Glucose & 1 \\
$\mathrm{HEPES}$ buffer & 2.38 \\
$\mathrm{CaCl}_{2}$ & 0.222 \\
$\mathrm{MgSO}_{4} 7 \mathrm{H}_{2} \mathrm{O}$ & 0.8118 \\
$\mathrm{FeCl}_{3} 6 \mathrm{H}_{2} \mathrm{O}$ & 0.001 \\
$\mathrm{MnCl}_{2}$ & 0.1145 \\
$\mathrm{Trace}$ element solution & $1 \mathrm{~mL} / \mathrm{L}$ \\
\hline
\end{tabular}

1240, Simadzu), was used as the indicator of the bacterial concentration [8, 13-14]. All chemicals in this study were purchased from Sigma-Aldrich Inc. and were of HPLC or analytical grade.

\subsection{Batch experiments for the oxidation of $\mathrm{Mn}$ (II)}

The oxidation of Mn(II) by P. putida MnB1 was carried out in $300 \mathrm{~mL}$ Erlenmeyer culture flasks (Duran). The bacterial suspension was inoculated to the flasks containing the liquid growth medium and Mn(II). To determine the effect of the initial Mn(II) concentration on $\mathrm{Mn}$ (II) oxidation rate, a series of Mn(II) oxidation experiments was performed at four different $\mathrm{Mn}$ (II) concentrations, ranging from 2 to $20 \mathrm{mg} / \mathrm{L}$, at $26^{\circ} \mathrm{C}$ and an initial $\mathrm{pH}$ of 5.56. The effect of $\mathrm{pH}$ on the oxidation of Mn was investigated by varying the $\mathrm{pH}$ in $1 \mathrm{pH}$ unit intervals, from 4.5 to 8.5 , at $26^{\circ} \mathrm{C}$ and an initial Mn(II) concentration in the Tebo medium of $12 \mathrm{mg} / \mathrm{L}$. 4-(2-hydroxyethyl)-1-piperazineethanesulfonic acid (HEPES, Sigma) was used as the buffer because it is known to be better at maintaining a physiological $\mathrm{pH}$, despite changes in the carbon dioxide concentration produced by cellular respiration, compared to bicarbonate buffers [15]. $\mathrm{HCl}$ and $\mathrm{NaOH}$ were used to adjust the initial $\mathrm{pH}$. The rates of $\mathrm{Mn}$ (II) oxidation were also determined at different temperatures, ranging from 20 to $30^{\circ} \mathrm{C}$, at $\mathrm{pH} 5.56$.

The Mn(II) concentration of the filtrate was analyzed according to Standard Methods [16], using a spectrophotometer (UVmini 1240, Simadzu), with the amount of Mn oxides in the liquid culture quantified by reaction with the reductive dye, Leucoberbelin blue I (LBB) [17]. Oxidized LBB is blue and the intensity of coloration is a function of the amount of Mn oxides having been reduced. The color intensity was measured for optical density at $618 \mathrm{~nm}$ using the spectrophotometer.

\subsection{Characterization of the biogenic Mn oxides.}

Mn oxides particles should be separated for examination of their properties by XRD and microscopy because organics and cell material accounted for more than $80 \%$ of the total resulting solid mass prior to the biological oxidation of Mn. The purification procedure aimed at ensuring the removal of organic materials (and absorbed anions and so on) that may interfere with the subsequent characterization. This involved a relatively harsh treatment to oxidize and dissolve the organic matter. The procedure reported by Mandernack et al. was adopted in this study, as described below [18].

1. Raw oxides in the suspension were collected in $40 \mathrm{~mL}$ vials and centrifuged for $20 \mathrm{~min}$ at $2000 \mathrm{rpm}$ and room temperature. The supernatant and visible solid cell materials settled on the Mn oxides were discarded, with the solids washed by shaking with deionized (DI) water for $5 \mathrm{~min}$. The above procedure was repeated 10 times.

2. Dissolution of the cell material using a 45 min sonication treatment with phenol, and subsequent 10 min sonication treatments with a phenol:chloroform (50:50, v/v) mixture, chloroform and a methanol:chloroform:water (12:5:3, v/v/v) mixture.

3. A 10-cycle DI water wash, as in step 1.

4. The suspension was acidified to $\mathrm{pH} 3$, shaken for $30 \mathrm{~min}$ and centrifuged. The supernatant solution was discarded to eliminate any absorbed Mn (II).

5. A 10-cycle DI water wash, as in step 1.

6. Oxidation of the remaining solid organic material was ac- 
complished by shaking for $4 \mathrm{hr}$ in $0.17 \% \mathrm{NaClO}$ solution. The high $\mathrm{pH}(>10)$ of this solution ensured the removal of absorbed anions.

7. A 10-cycle DI water wash, as in step 1.

For XRD analysis, the samples were oven-dried overnight at $60^{\circ} \mathrm{C}$, homogenized with a mortar and pestle and subjected to an $18 \mathrm{~kW}$ X-Ray diffractometer (M18XHF-SRA, MAC Science). The samples were mounted on a holder and scanned over the range of $2 \theta=5-90^{\circ}$. A field emission transmission electron microscope (FE-TEM, JEM-2100F, JEOL), operating at $200 \mathrm{kV}$, was used to acquire TEM images of the biogenic Mn oxides. For the TEM, the Mn oxides were dispersed in DI water, with a grain mount prepared by placing a drop of the suspension on a $3 \mathrm{~mm} \mathrm{Cu}$ grid, with holey carbon film, and left to dry in the air before its introduction into the TEM. Scanning electron micrographs were obtained using a field emission scanning electron microscope (FE-SEM, LEO SUPRA55, Carl Zeiss) via energy dispersive X-ray spectroscopy (Genesis 2000, EDAX).

\section{Results and Discussion}

\subsection{Growth of $P$. putida $\mathrm{MnB1}$}

The growth of $P$. putida strain MnB1 was initially investigated



to determine the experimental conditions for the oxidation of $\mathrm{Mn}(\mathrm{II})$ because the formation of Mn oxides occurs during different growth phases with different microbial strains. For example, the oxidation of $\mathrm{Mn}$ (II) takes place after the stationary phase with $P$. putida strains and Brachybacterium sp. Mn32 [19-20], but Mn oxides start to form from the log growth phase with Bacillus sp. WH4 [13]. Furthermore, the growth at different Mn(II) concentrations and the effects of $\mathrm{Pb}$ (II) and EE2 were also investigated.

Growth curves for P. putida MnB1, with different initial amounts of bacterial inoculation and $\mathrm{Mn}$ (II) concentrations are shown in Fig 1 . The acclimation period to the medium was $2-4 \mathrm{hr}$ for the bacteria, and an increase in the volume of initial bacterial suspension led to faster acclimation (Fig 1(a)). The growth rate during the exponential growth phase was not influenced by the amounts of the inoculant, and the populations during stationary phase, which was reached after approximately $24 \mathrm{hr}$, were nearly identical. Growth curves for the different initial Mn(II) concentrations are shown in Fig 1(b), which show no significant effect on the growth of $P$. putida MnB1 on varying the Mn(II) concentration. These results indicate that the effects of the initial Mn(II) concentration and amount of bacteria on the growth of $P$. putida $\mathrm{MnB1}$ were negligible. Meanwhile, the growth rate decreased in the presence of $\mathrm{Pb}(\mathrm{II})$ and $\mathrm{EE} 2$, but not significantly, as shown in Fig 2.

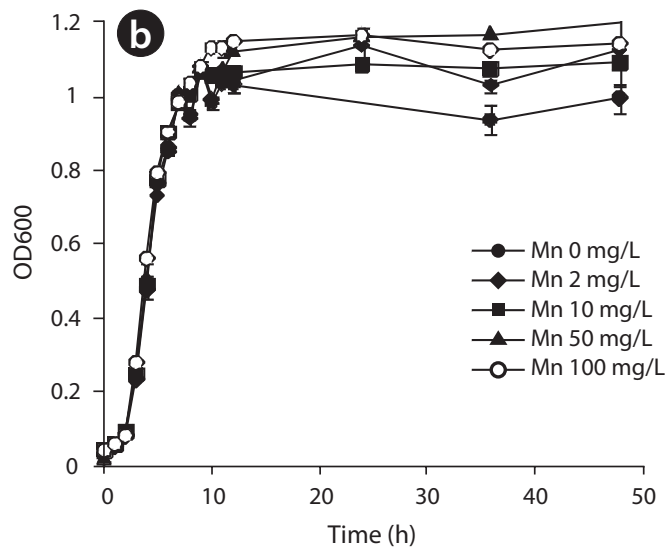

Fig. 1. Growth curves for P. putida MnB1 in solutions with different initial amounts of bacteria (a) and those with different initial Mn(II) concentrations (b).
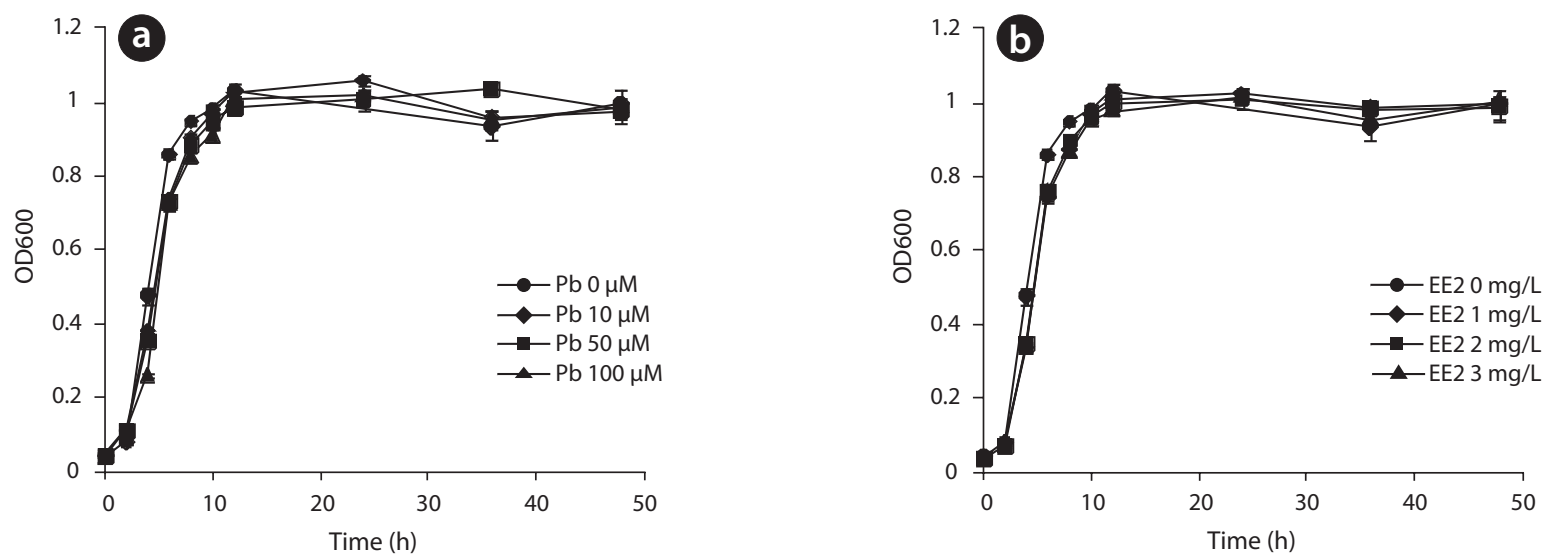

Fig. 2. Growth curves for P. putida $\mathrm{MnB1}$ in the presence of $\mathrm{Pb}$ (II) (a) and EE2 (b). 
The growth of $P$. putida MnB1 was slightly retarded, but not significantly, in presence of 10 to $100 \mu \mathrm{M} \mathrm{Pb}(\mathrm{II})$ or 1 to $3 \mathrm{mg} / \mathrm{L}$ EE2. However, the acclimation period and final population were not influenced, and the stationary phase was attained in approximately $24 \mathrm{hr}$, regardless of the presence or absence of $\mathrm{Pb}$ (II) or EE2. This indicates that the growth of P. putida MnB1 was not inhibited by the bulk phase $\mathrm{Pb}$ (II) or EE2, but by the amounts adsorbed, which was identical regardless of the initial concentration in the bulk phase. It has also been reported that the biosorption of metals and EE2 is negligible and their removal is dominantly contributed to by the Mn oxides in a system of $\mathrm{Mn}$ (II) and Mn oxidizing microorganisms. Sabirova et al. investigated the removal of EE2 using Leptothrix discophora and P. putida strains and found that the degradation of EE2 started after the generation of Mn oxides [19]. It was also reported by Wang et al. that $\mathrm{Zn}$ (II) and $\mathrm{Ni}$ (III) were not decreased until the Mn oxides had been generated by Bacillus sp. Mn32. Therefore, the negligible effects of $\mathrm{Pb}$ (II) and EE2 are suggested as being due to their minor accumulation on the cell surface [20].

\subsection{The oxidation of $\mathrm{Mn}$ (II) by P. putida $\mathrm{MnB} 1$ and the effects of $\mathrm{pH}$ and temperature}

The Mn(II) concentrations during $108 \mathrm{hr}$ of incubation with varying initial Mn(II) concentrations are shown in Fig 3. The oxidation of Mn(II) started after the stationary growth of $P$. putida
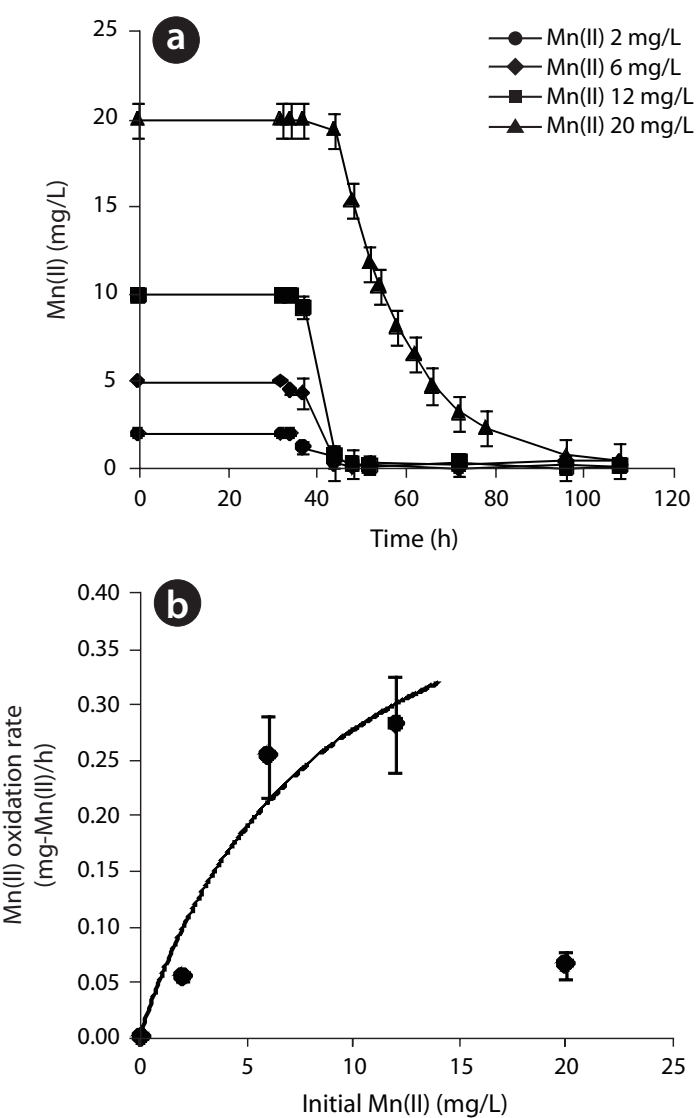

Fig. 3. The oxidation of Mn(II) by P. putida MnB1 with varying initial $\mathrm{Mn}$ (II) concentrations (a) and the rate of $\mathrm{Mn}$ (II) oxidation as a function of the Mn(II) concentration (b).
MnB1, as observed in the generation of Mn oxides by P. putida strains and Brachybacterium sp. Mn32 [19-20]. The $\mathrm{MnO}_{2}$ concentrations for 2, 5, 10, $20 \mathrm{mg}-\mathrm{Mn} / \mathrm{L}$ reached 3.171, 9.512, 19.024 and $31.706 \mathrm{mg} / \mathrm{L}$, respectively, which are close to the theoretical amounts. The increased initial $\mathrm{Mn}$ (II) concentration resulted in the generation of more $\mathrm{MnO}_{2}$, and the color of the medium and bacteria mixture became darker with increasing initial Mn(II) concentration following $108 \mathrm{hr}$ of the reaction, while the growth of $P$. putida MnB1 showed no dependency on the Mn(II) concentration (Fig 1). It has been accepted in many investigations that biogenic $\mathrm{Mn}$ (II) oxidation follows Michaelis-Menten enzyme kinetics, as presented in eq. (1) $[8,21]$, which was further verified by the study on the oxidation of $\mathrm{Mn}(\mathrm{II})$ using the purified enzyme from Acremonium sp. strain KR21-2 [22].

$$
-\frac{d[M n(I I)]}{d t} \frac{1}{X}=\frac{k[M n(I I)]}{K_{s}+[M n(I I)]}
$$

In eq. (1), $k$ is the maximum $\mathrm{Mn}$ (II) oxidation rate (mg-Mn/ mg-cell-min)], $K_{S}$ the half velocity constant (mg-Mn/) and $X$ the cell concentration (mg-cell/L), which was $391 \mathrm{mg} / \mathrm{L}$, by measuring the suspended solids in the bacterial suspension. which were assumed to be constant during the oxidation of $\mathrm{Mn}(\mathrm{II})$. The $k$ and $K_{\mathrm{s}}$ values were estimated to be $1.33 \times 10^{-3} \mathrm{mg}-\mathrm{Mn}(\mathrm{II}) /$ $\mathrm{mg}$-cell.h and $8.81 \mathrm{mg}-\mathrm{Mn} / \mathrm{L}$, respectively. Based on these parameters, $P$. putida $\mathrm{MnB1}$ was deemed less effective for the oxidation of Mn(II) than either Leptothrix discophora SS1 [8] or Pedomicrobium sp. ACM 3067 [21]. However, the oxidation of $\mathrm{Mn}$ (II) was inhibited at $20 \mathrm{mg}-\mathrm{Mn}$ (II)/L, although the growth of P. putida MnB1 was not influenced at $100 \mathrm{mg}-\mathrm{Mn}$ (II)/L. Tani et al. also reported the inhibition of the oxidation of $\mathrm{Mn}$ (II) at high $\mathrm{Mn}$ (II) concentrations in their study with Acremonium-like hyphomycete fungus, strain KR21-2 [23]. This infers that the inhibition was due to the obstruction of the mass transfer of Mn(II) from the bulk phase to the cell surface due to the accumulation of Mn oxides particles. Toner et al. presented TEM images of the Mn oxides accumulated on the extracellular organic matrix [24], and Saratovsky et al. observed MnOx nucleation on the exopolysacharride sheath surrounding L. discophora SP6 [9]. MnOx solids aggregations were found not only on cell surfaces, but also around the purified enzyme [22]. However, the growth of $P$. putida $\mathrm{MnB1}$ was not affected, even at high Mn(II) concentrations, because the oxidation of $\mathrm{Mn}$ (II) and; therefore, Mn oxides accumulation started after the stationary phase (Fig 1(b) and 3). Meanwhile, with an initial Mn(II) concentration of $20 \mathrm{mg} / \mathrm{L}$, all the $\mathrm{Mn}$ (II) was consumed to form a stoichiometric amount of $\mathrm{MnO}_{2}$, indicating the abundance of Mn oxidizing enzymes in the experimental system.

The $\mathrm{MnO}_{2}$ concentrations with respect to reaction time at different initial pH are illustrated in Fig 4 (a). The maximum rate of $\mathrm{MnO}_{2}$ generation was observed at $\mathrm{pH} 7.43$, but this was slightly lower at $\mathrm{pH}$ 8.22. However, when the initial $\mathrm{pH}$ was 5.56, the rate of biogenic Mn oxides generation was decreased significantly and lag phase increased dramatically. No Mn oxides were formed at an initial $\mathrm{pH}$ of 4.59. These results show that the $\mathrm{Mn}$ (II)-oxidizing enzyme was active at $\mathrm{pH}$ higher than 5.56. The rates of $\mathrm{Mn}$ (II) oxidation at various initial $\mathrm{pH}$ are shown in Fig 4 (b). As the pH decreased from 8.22 to 5.56 , the rate of Mn(II) oxidation for P. putida MnB1 decreased, with a linear relationship obtained. The optimum $\mathrm{pH}$ was between 7.43 and 8.22 , which was in agreement with the findings in many studies, in that the biologic oxidation of $\mathrm{Mn}$ (II) was strongly inhibited at $\mathrm{pH}$ values 
less than 6. Leptothrix discophora SS1 showed a maximum rate of $\mathrm{Mn}$ (II) oxidation at $\mathrm{pH} 7.5$, but this was significantly decreased below pH 6.5 and over pH 8.5 [8]. In addition, Larsen et al. also reported the maximum $\mathrm{Mn}$ (II) oxidation activity of Pedomicrobium sp. ACM 3067 at $\mathrm{pH}$ 7, which decreased sharply at below pH 5.5 and above pH 7 [21]. Fig 4 (c) shows the pH changes with different initial $\mathrm{pH}$ values during microbial growth and $\mathrm{Mn}$ (II) oxidation over a $72 \mathrm{hr}$ period. Before the microbial population had attained the stationary phase, the $\mathrm{pH}$ decreased, started to recover, approached the initial value and slowly increased
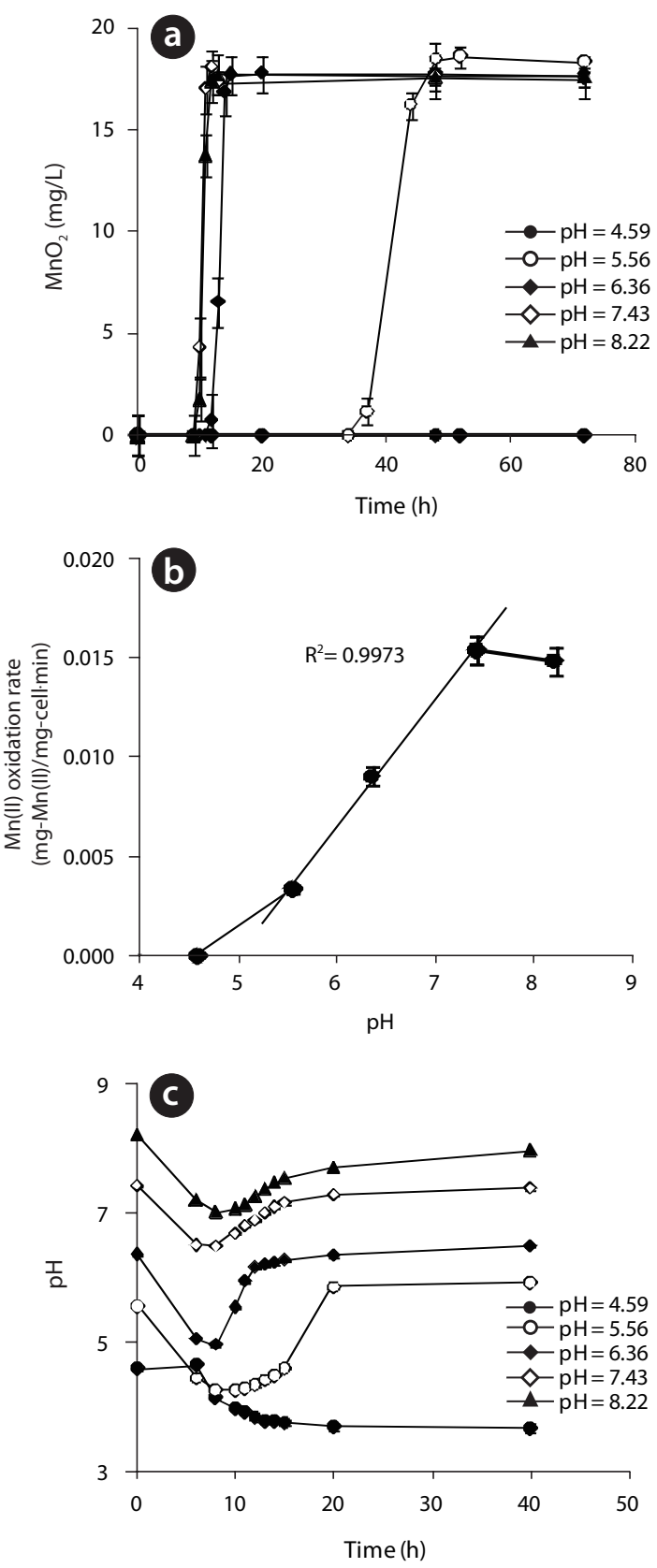

Fig. 4. The generation of Mn oxides by P. putida MnB1 at different initial $\mathrm{pH}$ values (a), the rate of $\mathrm{Mn}$ (II) oxidation as a function of the initial $\mathrm{pH}(\mathrm{b})$ and $\mathrm{pH}$ changes during the oxidation of $\mathrm{Mn}$ at different initial $\mathrm{pH}$ values (c). to the original $\mathrm{pH}$ after the completion of $\mathrm{Mn}$ (II) oxidation. No $\mathrm{pH}$ recovery was observed at $\mathrm{pH} 4.59$, when no Mn oxides were formed at all.

Manganese-oxidizing microorganisms are known to be both $\mathrm{pH}$ and temperature sensitive. The production of $\mathrm{Mn}(\mathrm{II})$ at different temperatures, ranging from 20 to $30^{\circ} \mathrm{C}$, at pH 5.56 and an initial Mn(II) of $12 \mathrm{mg} / \mathrm{L}$ is shown in Fig 5 (a). The rate of Mn(II) oxidation as a function of the temperature is also shown in Fig 5 (b). $\mathrm{Mn}(\mathrm{II})$ was not oxidized at 28 or $30^{\circ} \mathrm{C}$, but Mn oxides formed under $26^{\circ} \mathrm{C}$, with an optimum temperature of $24^{\circ} \mathrm{C}$, with the shortest lag phase and highest rate of $\mathrm{Mn}$ (II) oxidation. In addition, The oxidation of Mn(II) by P. putida MnB1 was more sensitive to temperature than that by Pedomicrobium sp. ACM 3067, with no great decrease in the rate of $\mathrm{Mn}$ (II) oxidation observed between 20 and $30^{\circ} \mathrm{C}$ [21]. The increase in the rate of $\mathrm{Mn}$ (II) oxidation between 20 and $24^{\circ} \mathrm{C}$ was mainly attributed to the temperature activation of the reaction, while the decrease above $24^{\circ} \mathrm{C}$ was possibly attributed to the thermal deactivation of the Mn-oxidizing enzyme $[8,25]$.

\subsection{Property of the biogenic Mn oxides}

The XRD patterns of the biogenic Mn oxides formed by $P$. putida $\mathrm{MnB1}$ and birnessite are presented in Fig 6 . Birnessite showed distinctive peaks at $2 \theta$ of 12.3 and $24.8^{\circ}$; whereas, the
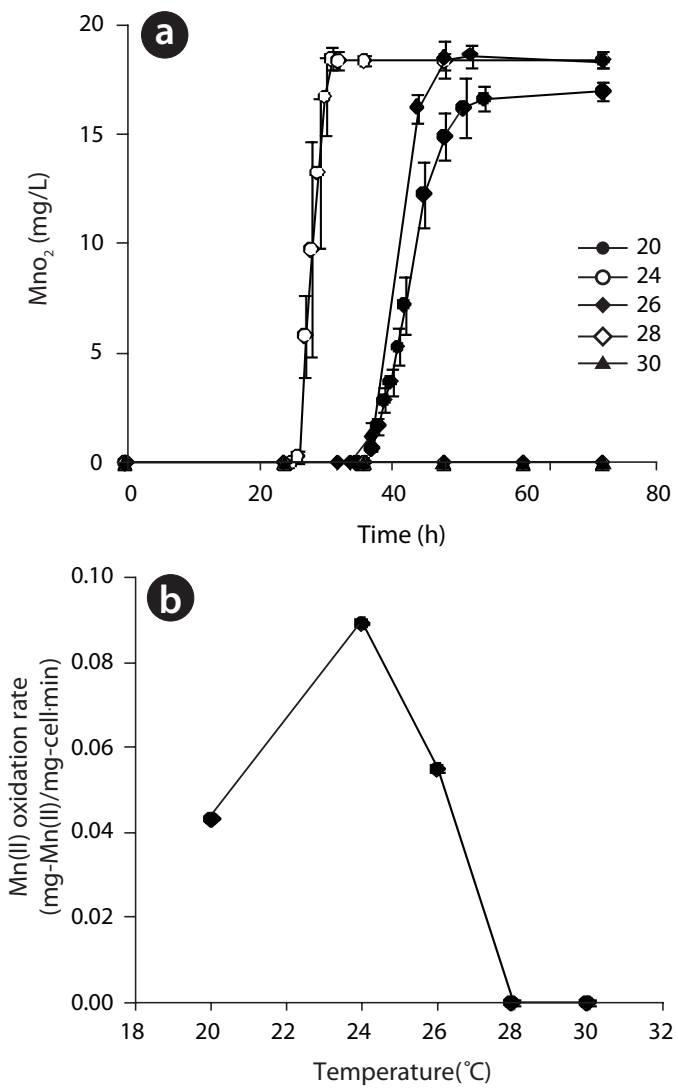

Fig. 5. The generation of Mn oxides by P. putida MnB1 at different temperatures (a) and the rate of Mn(II) oxidation as a function of temperature. 


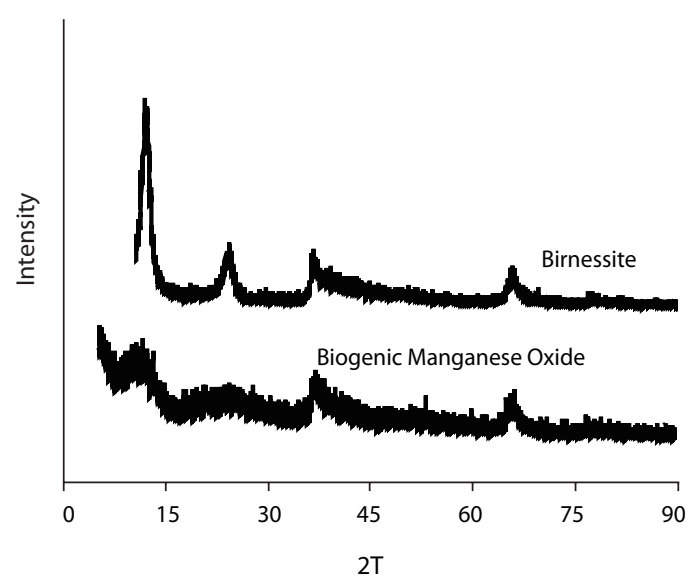

Fig. 6. XRD patterns of abiotic and biogenic Mn oxides.

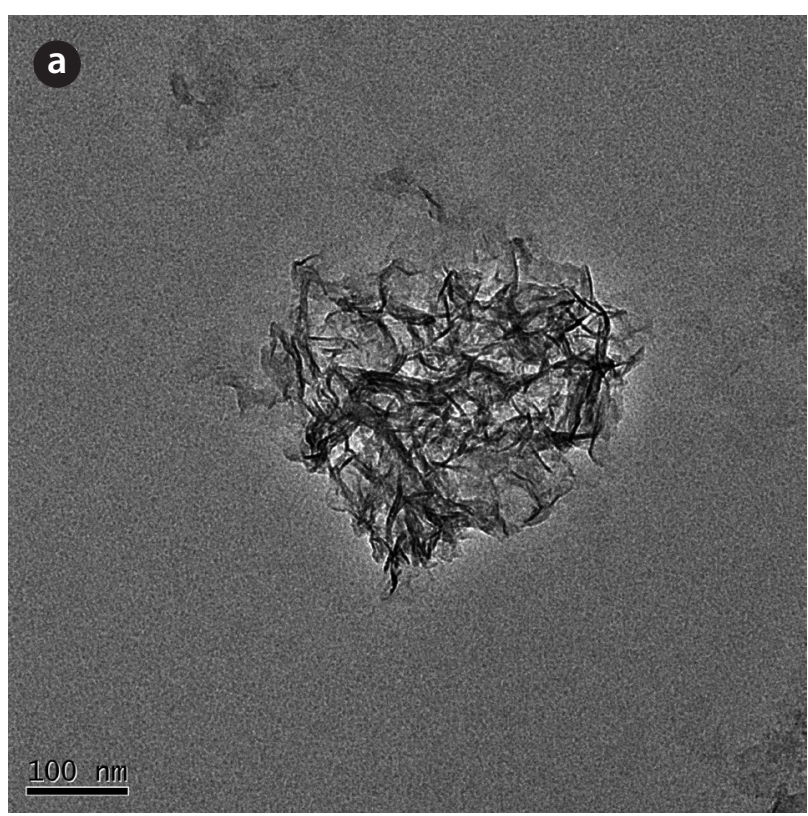

biogenic Mn oxides exhibited broader peaks of lower amplitude in this region. However, the XRD patterns of both the biogenic and abiotic Mn oxides showed small peaks at $2 \theta$ of 35 and $65^{\circ}$. These peaks were typical of varnadite, a fine-grained, poorly crystalline, natural Mn oxide phase found in the oxidized zone of Mn ore deposits, which is considered a major phase in ocean Mn nodules and other Mn oxide crusts and coatings [26]. The TEM image and EDS analysis of the biogenic Mn oxides showed the aggregation of small particles, with irregular shape, confirming the poor crystallinity (Fig 7). The SEM image also shows shape irregularity compared to birnessite (Fig 8).

Biogenic Mn oxides are generally known to be poorly crystalline compared to abiotic Mn oxides. Biogenic Mn oxides have intermediate crystallinity and reactivity, between those of synthetic phyllomanganates $\delta-\mathrm{MnO}_{2}$ and acid birnessite, which are formed through the reduction of permanganate with $\mathrm{MnCl}_{2}$ or $\mathrm{HCl}$, respectively $[5,12]$. The X-ray Absorption Near Edge Structure (XANES), Extended X-ray Absorption Fine Structure (EXAFS) spectra and X-ray Diffraction (XRD) intensity data of the biogenic Mn oxides produced by the spores of marine Bacillus sp. strain SG-1 indicated that the primary biogenic oxides were fine particulate phyllomanganates, with $10 \AA$ basal plane spacing [27]. The diameters of the particles vary widely, but most were approximately 200 to $400 \mathrm{~nm}$ in diameter [28].

\section{Conclusions}

The growth of $P$. putida MnB1 and the generation of Mn ox-

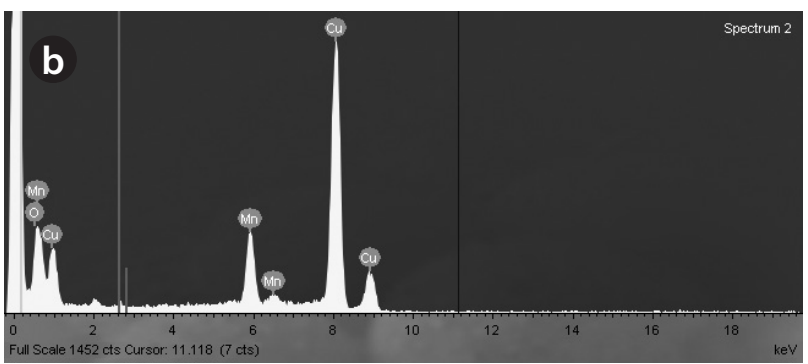

Fig. 7. TEM image (a) and EDS (b) of the biogenic Mn oxides formed by P. putida MnB1.


Fig. 8. SEM images of the biogenic Mn oxides formed by P. putida MnB1 (a) and abiotic $\mathrm{MnO}_{2}$ 
ides were investigated to characterize the biogenic oxidation of Mn by $P$. putida MnB1. The acclimation period, growth rate in the exponential growth phase and population during the stationary phase of $P$. putida MnB1 were not influenced by the initial Mn(II) concentration, while a higher initial amount of inoculum decreased the lag phase. A slight decrease in the growth rate of $P$. putida $\mathrm{MnB} 1$ was observed in the presence of both $\mathrm{Pb}$ (II) and EE2, but the growth curves for 10 to $100 \mu \mathrm{M} \mathrm{Pb}$ (II) and 1 to $3 \mathrm{mg} / \mathrm{L}$ EE2 were almost identical. This indicates the adsorption of $\mathrm{Pb}$ (II) and EE2 onto the cell surface of P. putida MnB1 was insignificant.

Poorly crystalline, nano-sized biogenic Mn oxides were formed in a system containing P. putida MnB1, Mn(II) and liquid growth medium. The optimum conditions for the maximum rate of $\mathrm{Mn}$ oxidation were $10 \mathrm{mg}-\mathrm{Mn} / \mathrm{L}, \mathrm{pH} 7.43-8.22$ and $24^{\circ} \mathrm{C}$. The biogenic oxidation of Mn by P. putida MnB1 followed Michaelis-Menten enzyme kinetics, but was retarded at $20 \mathrm{mg}-\mathrm{Mn}(\mathrm{II}) / \mathrm{L}$, although the amount of Mn oxides generated was almost stoichiometric. This indicates an abundance of Mnoxidizing enzyme and the obstruction of mass transfer from the bulk phase $\mathrm{Mn}$ (II) to the cell surface due to the accumulation of Mn oxides on the extracellular enzyme layer. The oxidation of Mn by P. putida MnB1 was very both $\mathrm{pH}$ and temperature sensitive, with optimum ranges of 7.43 to 8.22 and about $24^{\circ} \mathrm{C}$, respectively.

\section{Acknowledgement}

This work was supported by a Korea Research Foundation Grant, funded by the Korean Government (KRF-2009-0076579).

\section{References}

1. Zhang H, Huang CH, Oxidative Transformation of Triclosan and Chlorophene by Manganese Oxides. Environ. Sci. Technol. 2003; 37: 2421-2430.

2. Tipping E, Heaton MJ,. The adsorption of aquatic humic substances by two oxides of manganese. Geochim. Cosmochim. Ac. 1983; 47: 1393-1397.

3. De Rudder J, Wiele TV, Dhooge W, Comhaire F, Verstraete W, Advanced water treatment with manganese oxide for the removal of 17a-ethynylestradiol (EE2). Water Res. 2004; 38: 184-192.

4. Zhao L, Yu ZQ, Peng PA, Huang WL, Dong YH, Oxidative transformation of tetrachlorophenols and trichlorophenols by manganese dioxide. Environ. Toxicol. Chem. 2009; 28: 1120-1129.

5. Tebo BM, Bargar JR, Clement BG, Dick GJ, Murray KJ, Parker D, Verity R, Webb SM, Biogenic manganese oxides: properties and mechanisms of formation. Annu. Rev. Earth Planet. Sci. 2004; 32: 287-328.

6. Hennebel T, De Gusseme B, Boon N, Verstraete W, Biogenic metals in advanced water treatment. Trends Biotechnol. 2009; 27: 90-98.

7. Van Waasbergen LG, Hildebrand M, Tebo BM, Identification and characterization of a gene cluster involved in manganese oxidation by spores of the marine Bacillus sp. strain SG-1. J. Bacteriol. 1996; 178: 3517-3530.

8. Zhang J, Lion LW, Nelson YM, Shuler ML, Ghiorse WC, Kinetics of Mn(II) oxidation by Leptothrix discophora SS1. Geo- chim. Cosmochim. Ac. 2002; 66: 773-781.

9. Saratovsky I, Wightman PG, Pasten PA, Gaillard JF, Poeppelmeier KR, Manganese oxides: Parallels between abiotic and biotic structures. J. Am. Chem. Soc. 2006; 128: 11188-11198.

10. Caspi R, Haygood MG, Tebo BM, Unusual ribulose-1, 5-bisphosphate carboxylase/oxygenase genes from a marine manganese-oxidizing bacterium. Microbiology 1996; 142: 2549-2559.

11. Caspi R, Tebo BM, Haygood MG, c-Type cytochromes and manganese oxidation in Pseudomonas putida MnB1. Appl. Environ. Microb. 1998; 64: 3549-3555.

12. Villalobos M, Toner B, Bargar J, Sposito G, Characterization of the Mn oxide produced by Pseudomonas putida strain MnB1. Geochim. Cosmochim. Ac. 2003;67:2649-2662.

13. Meng YT, Zheng YM, Zhang LM, He JZ. Biogenic Mn oxides for effective adsorption of $\mathrm{Cd}$ from aquatic environment. Environ. Pollut. 2009; 157: 2577-2583.

14. Novak M, Pfeiffer T, Ackermann M, Bonhoeffer S, Bacterial growth properties at low optical densities. Anton. Leeuw. 2009; 96: 267-274.

15. Baicu SC, Taylor MJ, Acid-base buffering in organ preservation solutions as a function of temperature: new parameters for comparing buffer capacity and efficiency. Cryobiology 2002; 45: 33-48.

16. APHA. Standard Methods for the Examination of Water and Wastewater. $20^{\text {th }}$ Ed. American Health Association, Washington: DC; 1998.

17. Tebo BM, Clement BG, Dick GJ, Biotransformations of manganese. Manual of Environmental Microbiology, 3rd ed. 2007; 1223-1238.

18. Mandernack KW, Fogel ML, Tebo BM, Usui A, Oxygen isotope analyses of chemically and microbially produced manganese oxides and manganates. Geochim. Cosmochim. Ac. 1995; 59: 4409-4425.

19. Sabirova JS, Cloetens LFF, Vanhaecke L, Forrez I, Verstraete $\mathrm{W}$, Boon N, Manganese-oxidizing bacteria mediate the degradation of 17a-ethinylestradiol. Microbial Biotechnology 2008; 1(6): 507-512.

20. Wang W, Shao Z, Liu Y, Wang G, Removal of multi-heavy metals using biogenic manganese oxides generated by a deepsea sedimentary bacterium - Brachybacterium sp. strain Mn32. Microbiology 2009; 55: 989-1996.

21. Larsen EI, Sly LI, McEwan AG, Manganese(II) adsorption and oxidation by whole cells and a membrane fraction of Pedomicrobium sp. ACM 3067. Arch. Microbiol. 1999; 171: 257-264.

22. Miyata N, Tani Y, Maruo K, Tsuno H, Sakata M, Iwahori K, Manganese(IV) oxide production by Acremonium sp. strain KR21-2 and extracellular Mn(II) oxidase activity. Appl. Environ. Microb. 2006; 72(10): 6467-6473.

23. Tani Y, Ohashi M, Miyata N, Seyama H, Iwahori K, Soma M, Sorption of $\mathrm{Co}(\mathrm{II}), \mathrm{Ni}(\mathrm{II})$, and $\mathrm{Zn}$ (II) on biogenic manganese oxides produced by a Mn-oxidizing fungus, Strain KR21-2, J. Environ. Sci. Heal. 2005; 39(10): 2641-2660.

24. Toner B, Fakra S, Villalobos M, Warwick T, Sposito G, Spatially resolved characterization of biogenic manganese oxide production within a bacterial biofilm. Appl. Environ. Microb. 2005; 71(3): 1300-1310.

25. Francis CA, Tebo BM. Enzymatic Manganese(II) Oxidation by Metabolically Dormant Spores of Diverse Bacillus Species. Appl. Environ. Microb. 2002; 68: 874-880.

26. Post JE, Manganese oxide minerals: crystal structures and 
economic and environmental significance. In: National Academy of Sciences of the United States of America; 1999; 96: 3447-3454.

27. Bargar JR, Webb SM, Tebo BM, EXAFS, XANES and in-situ SR-XRD characterization of biogenic manganese oxides pro- duced in sea water. Phys. Scripta 2005; 155: 888-890.

28. Krekeler MPS, Transmission electron microscopy (TEM) investigations of Mn-oxide rich cathodic material from spent disposable alkaline batteries. Waste Manage. 2008; 28: 20612069. 